\title{
Local adaptation and maternal effects in two species of marine gastropod (genus Crepidula) that differ in dispersal potential
}

\author{
Steven Untersee*, Jan A. Pechenik \\ Biology Department, Tufts University, Medford, Massachusetts 02155, USA
}

\begin{abstract}
Adaptation to local conditions should be less likely in species with wide dispersal since periodic immigration from populations not under selection would counteract the short-term results of local selection. To test this hypothesis, we used 2 species of sympatric marine gastropods of the genus Crepidula that have vastly different early life dispersal stages. Offspring of $C$. fornicata emerge as long-lived free-swimming larvae, whereas offspring of $C$. convexa emerge as benthic juveniles. We investigated the local adaptation of each species at 2 locations by assessing their tolerance to the toxic metal copper in the laboratory. We conducted $96 \mathrm{~h}$ acute copper toxicity tests with juveniles of $C$. convexa and larvae of $C$. fornicata released in the laboratory by adults collected from a reference site (Lynn Harbor, Nahant, Massachusetts, USA) or a polluted site (New Bedford Harbor, Fairhaven, Massachusetts). To test for maternal effects, we also raised C. fornicata released in the laboratory ( $F_{1}$ generation) to sexual maturity and tested for differences in copper tolerance of their offspring $\left(F_{2}\right)$. As expected, juveniles of $C$. convexa from the polluted site were significantly more copper tolerant than juveniles from the reference site $(\mathrm{p} \leq 0.05)$, suggesting local adaptation at the polluted site. Contrary to expectations, $F_{1}$ larvae of $C$. fornicata from the polluted site were not equally copper tolerant, but less copper tolerant than $\mathrm{F}_{1}$ larvae from the reference site. However, copper tolerance did not differ for $\mathrm{F}_{2}$ larvae of $C$. fornicata from the 2 sites. Our results suggest that populations of $C$. convexa can adapt to locally high metal concentrations, while populations of $C$. fornicata cannot, probably because of the periodic input of $C$. fornicata larvae from distant populations that do not experience high metal stress. Also, long-term exposure of $C$. fornicata adults to pollutants apparently decreased the copper tolerance of their offspring ( $F_{1}$ generation), an effect not seen in the laboratory-propagated $\mathrm{F}_{2}$ generation.
\end{abstract}

KEY WORDS: Crepidula $\cdot$ Local adaptation $\cdot$ Dispersal $\cdot$ Copper $\cdot$ Maternal effects $\cdot$ Pollution $\cdot$ Metals Resale or republication not permitted without written consent of the publisher

\section{INTRODUCTION}

Genetic adaptation to environmental stress through selection is the basis for evolution, but for many species this occurs over time scales too long to study directly. Local adaptation of a species across a heterogeneous environment allows the study of the evolution of traits across space instead of across time. Whether a species will adapt to local conditions depends partly on the amount of gene flow between populations under different degrees of selective pressure (Kawecki \&
Ebert 2004). High gene flow between areas differing in the magnitude of a particular environmental stress will offset local adaptation, while limited gene flow between such areas will tend to maintain it (Kawecki \& Ebert 2004). The strength of the selection and the consistency of its spatial heterogeneity over time will also affect whether a given species will become locally adapted (Kawecki \& Ebert 2004).

Metals are persistent in marine sediments and some, like copper, are essential trace elements. Selection should therefore act strongly on an organism's ability 
to control the uptake, metabolism, and detoxification of such essential metals. Yet there have been few studies demonstrating evolved tolerance to metals in marine invertebrates (reviewed by Morgan et al. 2007) despite good evidence for the ability to evolve metal tolerance in freshwater invertebrates (Klerks \& Levinton 1989, Ward \& Robinson 2005) and vertebrates (Xie \& Klerks 2004a). The role that dispersal may play in the ability of benthic marine invertebrates to adapt to localized sources of pollution has been considered in only 1 study, in which 2 species of crab and an amphipod were compared (Rainbow et al. 1999), and has never been examined for congeners. Marine invertebrates are particularly well suited for such studies, due to their diverse reproductive modes and the corresponding differences in dispersal potential.

In the present study we asked whether sister species in the genus Crepidula have evolved tolerance to copper at a highly polluted site in Massachusetts and whether the ability to evolve increased tolerance to copper has been limited in 1 species by dispersal during development. Unlike most gastropods, the 2 species in this study, C. fornicata and C. convexa, are suspension feeders: they have modified gills with unusually large surface areas that are efficient in particle capture (Fretter \& Graham 1994) and may also, therefore, enhance uptake of water-borne pollutants. Females of $C$. fornicata release veliger larvae that remain planktonic for at least 3 to $4 \mathrm{wk}$ (Pechenik 1984); thus, there is considerable potential for dispersal during development, which should limit the potential for local adaptation (Bohonak 1999, Kawecki \& Ebert 2004). In contrast, females of C. convexa release fully developed juveniles (Conklin 1897) that have a much lower potential for dispersal during development. Although high dispersal potential does not guarantee high gene flow (e.g. Burton \& Feldman 1981, and reviewed in Bohonak 1999), Collin (2001) showed through analyses of mitochondrial DNA that C. convexa along the Atlantic and Gulf coasts of North America had a much higher level of population differentiation than $C$. fornicata, a finding that is consistent with the hypothesized differences in realized dispersal and gene flow. We predicted, therefore, that local adaptation to high metal stress should be more likely for populations of $C$. convexa than for populations of $C$. fornicata.

\section{MATERIALS AND METHODS}

Animal collection and care. We chose to work at 2 sites in Massachusetts - New Bedford Harbor in Fairhaven and Lynn Harbor in Nahant - where both species co-exist. New Bedford Harbor has been listed on the USEPA National Priorities List, also known as the Superfund list, since 1983 (for site description and history, see www.epa.gov/ne/nbh/history.html) because of the high concentrations of polychlorinated biphenyl (PCB) contamination of the sediments, and the accompanying high concentrations of various metals (e.g. Cu, Cd, Ni) and polycyclic aromatic hydrocarbons (PAHs) (Pruell et al. 1990). We chose our reference site, Nahant, based on much lower concentrations of metals in the soft tissue of Mytilus edulis (Robinson et al. 1990).

We collected adult Crepidula fornicata and C. convexa from both sites. All animals (adults and their offspring) were kept in the laboratory in artificial seawater (Instant Ocean, 30\% salinity) at room temperature (approximately $23^{\circ} \mathrm{C}$ ). Adults were fed daily with either Isochrysis galbana (clone T-ISO) or Dunaliella tertiolecta (clone DUN) at an initial concentration of approximately $20 \times 10^{4}$ cells ml ${ }^{-1}$. Larvae or juveniles were separated from adults after emergence, and fed daily with T-ISO or DUN for 5 to $26 \mathrm{~d}$. This feeding period was intended to give all offspring sufficient energy reserves to minimize the effects of starvation during the acute toxicity tests. Since the length of this feeding period differed among tests, we checked for an effect of offspring age on copper tolerance $\left(\mathrm{LC}_{50}\right)$ by linear regression. The offspring were starved for 3 to $5 \mathrm{~d}$ before the toxicity tests to avoid fecal contamination; metals, including copper, are known to bind to organic matter (Rand 1995) and differences in fecal matter among replicates could therefore lead to differences in dissolved copper exposure concentrations. Most offspring were released by their mothers in the laboratory, and had never been in the field (offspring in 3 initial experiments were brooded in the field and released by their mothers in the laboratory).

$96 \mathrm{~h}$ acute copper toxicity tests. Juveniles of Crepidula convexa and larvae of $C$. fornicata from both sites were tested for their copper tolerance by exposing them to dissolved copper in the laboratory for $96 \mathrm{~h}$ $\left(20^{\circ} \mathrm{C}, 30 \%\right.$ salinity). We used these developmental stages because they are the first free-living stages for each species, and their copper tolerance could be measured without previous exposure of the offspring to copper. The copper tolerance of these offspring should therefore reflect heritable genetic differences in copper tolerance, rather than physiological acclimation. These tests were not intended to model selection, but rather to determine whether the population from the polluted site showed increased copper tolerance. Acute toxicity tests necessarily expose individuals to higher toxicant concentrations than would be needed to exert selective pressure under conditions of chronic exposure. Each test was performed using offspring released on the same day from a unique 
female. Procedures for both species were the same except where noted.

For initial experiments, we used the first offspring released from adults for toxicity tests. Later, the first offspring were not used unless they were released at least 1 mo after the adults had been brought into the laboratory to ensure that the offspring had not been exposed to field concentrations of metals as embryos. All offspring were visually inspected at 8 to $20 \times$ magnification, and any that were morphologically abnormal or inactive were excluded from the tests.

We made all copper solutions by serial dilution from a $10 \mathrm{mg} \mathrm{l}^{-1}$ copper stock solution $\left(\mathrm{CuCl}_{2}\right)$ that was prepared no more than $24 \mathrm{~h}$ before starting each experiment. All solutions were changed daily. Offspring were not fed during the tests, as the presence of phytoplankton can influence the availability of dissolved copper to the snails (Xie et al. 2005). We made solutions on the day they were used with aerated $0.22 \mu \mathrm{m}$ filtered autoclaved artificial seawater (Instant Ocean) containing $50 \mathrm{mg} \mathrm{l}^{-1}$ streptomycin and $40 \mathrm{mg}$ $\mathrm{I}^{-1}$ penicillin (according to Lord 1986) to limit bacterial growth; higher mortality in some replicate containers could otherwise have triggered bacterial growth, which itself could have led to additional mortality not directly caused by exposure to copper. Offspring were haphazardly selected from a single group of offspring and transferred by pipette to a bath of the appropriate copper concentration (to prevent dilution of the test solutions), and then transferred from the bath to each test container ( 3 to 4 replicates, each with $3 \mathrm{ml}$ of solution in 1 well of an acid-washed 12-well plastic tissue culture plate).

The initial tests consisted of 4 replicates of 4 tested copper concentrations ( 0 to $1000 \mu \mathrm{g} \mathrm{l}^{-1}$ ) with 8 juveniles of Crepidula convexa or 20 larvae of $C$. fornicata per replicate. Later tests included only 3 replicates but tested 7 copper concentrations ( 0 to $1000 \mu \mathrm{g} \mathrm{l}^{-1}$ ) with either 4 to 8 juveniles of $C$. convexa (depending on the number of juveniles available) or 10 larvae of C. fornicata.

After 96 h, we checked all offspring at 32 to $50 \times$ magnification for evidence of activity, including swimming, muscular movement (either spontaneous or in response to quick changes in lighting), or a heartbeat (visible through the shell, only for larvae). Any offspring lacking all of these were determined to be dead.

Maternal effects on copper tolerance. Although all offspring were kept in controlled conditions in the laboratory, their parents were collected in the field, and so parents from different sites experienced different conditions before they were collected. These differences may have caused differences in the hardiness of their offspring (Bayne et al. 1975). Snails collected from the polluted site may not have provided for their offspring as well as those that grew up at the lesspolluted reference site. To test this hypothesis, adults of both species were collected from both sites (P generation) and their offspring $\left(\mathrm{F}_{1}\right)$ were raised to sexual maturity in controlled conditions in the laboratory. We then paired the $F_{1}$ juveniles with non-siblings, reared them to adulthood in the laboratory, and performed $96 \mathrm{~h}$ acute copper toxicity tests on their offspring $\left(\mathrm{F}_{2}\right)$ as described above. Time from hatching to sexual maturity was approximately 5 to 7 mo for each generation of the 2 species. Unfortunately, an incubator malfunction resulted in the death of the entire Crepidula convexa $\mathrm{F}_{1}$ generation before they produced offspring. Fortunately, data for the $\mathrm{F}_{2}$ generation were critical for interpreting our results for C. fornicata, but not for C. convexa.

Data analysis. We calculated the median lethal concentration $\left(\mathrm{LC}_{50}\right)$ for each group of offspring by either the Spearman-Karber method when mortalities in the lowest and highest concentrations were 0 and $100 \%$, respectively, or the trimmed Spearman-Karber method when the above conditions were not met (US Environmental Protection Agency 2002). We used software originally developed at Montana State University and obtained from the website of the US Environmental Protection Agency (www.epa.gov/ ceampubl/fchain/lc50/). We performed linear regressions of data to assess whether offspring age affected their tolerance of copper. Since we tested a different developmental stage for each species, no comparisons of metal tolerance were made directly between species; we tested only for intraspecies differences in copper tolerance between sites or generations. Differences between $\mathrm{LC}_{50}$ values for Crepidula convexa from both sites were analyzed using a pooled variances $t$-test. Differences between $\mathrm{LC}_{50}$ values for both generations $\left(\mathrm{F}_{1}\right.$ and $\left.\mathrm{F}_{2}\right)$ of $C$. fornicata from both sites were analyzed using a 2-way Model I ANOVA. Bonferroni post hoc comparisons (4 comparisons, so $\alpha=$ 0.0125) were performed to test for differences between sites for each generation $\left(F_{1}\right.$ and $\left.F_{2}\right)$ and between generations for each site (reference and polluted). All statistical analyses were performed according to Zar (1999) using the statistical software Systat v.10 or by hand (Bonferroni post hoc comparisons). Since the results from the initial experiments did not appear to deviate from results for later tests (see Fig. 2a,b), they were not excluded from statistical analysis.

\section{RESULTS}

Offspring age (and therefore the length of the feeding period before the test) had no effect on the copper 
tolerance for either species. Age did not affect the copper tolerance $\left(\mathrm{LC}_{50}\right)$ of juveniles of Crepidula convexa (Fig. 1a, linear regressions, reference site: $F_{1,2}=0.24$, $\mathrm{p}=0.68$; polluted site: $F_{1,1}=8.93, \mathrm{p}=0.21$; data from both populations analyzed together: $F_{1,5}=4.38, \mathrm{p}=$ 0.09). Similarly, age did not affect the copper tolerance of $F_{1}$ generation larvae of $C$. fornicata from either population (Fig. 1b, linear regressions, reference site: $F_{1,2}=$ $0.01, \mathrm{p}=0.92$; polluted site: $F_{1,3}=0.09, \mathrm{p}=0.79$; both populations: $F_{1,7}=1.23, \mathrm{p}=0.31$ ), nor the copper tolerance of $\mathrm{F}_{2}$ generation larvae (Fig. 1C, linear regressions, reference site: $F_{1,5}=0.94, \mathrm{p}=0.38_{\text {; }}$ polluted site: $F_{1,1}=$ $2.52, \mathrm{p}=0.36$; both populations: $F_{1,8}=2.72, \mathrm{p}=0.14$ ).

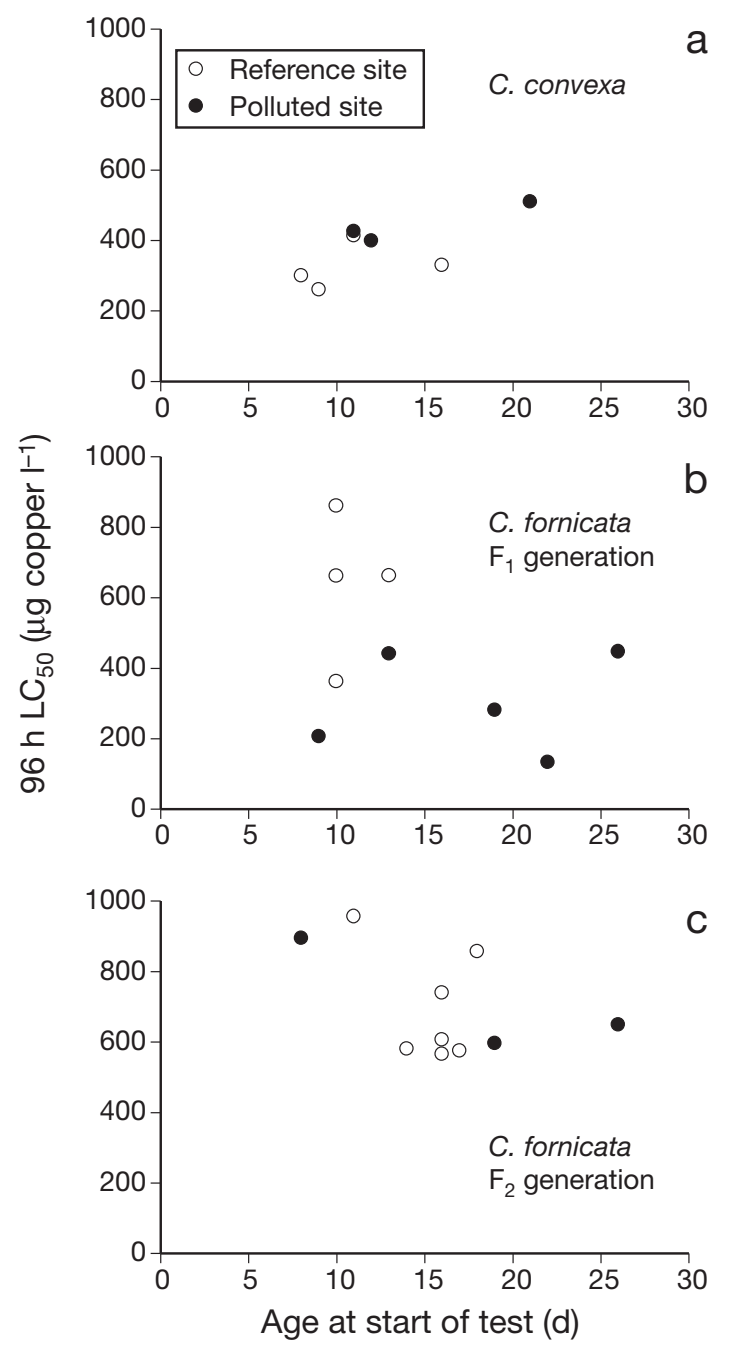

Fig. 1. Crepidula convexa and C. fornicata. Age and median lethal concentration $\left(\mathrm{LC}_{50}\right)$ of copper for (a) juveniles of C. convexa and (b, c) larvae of C. fornicata. Each point represents one $96 \mathrm{~h}$ acute copper toxicity test with offspring from a unique set of parents. Each test consisted of 3 or 4 replicates with 4 to 8 juveniles or 10 to 20 larvae at each of 4 to 7 copper concentrations ( 0 to $1000 \mu \mathrm{g} \mathrm{l}^{-1}$ ). We tested for an effect of the age of the offspring on their copper tolerance $\left(\mathrm{LC}_{50}\right)$ by linear regression
Mortalities for juveniles of Crepidula convexa in $96 \mathrm{~h}$ acute copper toxicity tests are shown in Fig. 2a (note that the results of initial tests were very similar to the results of later tests from the same site). Juve-
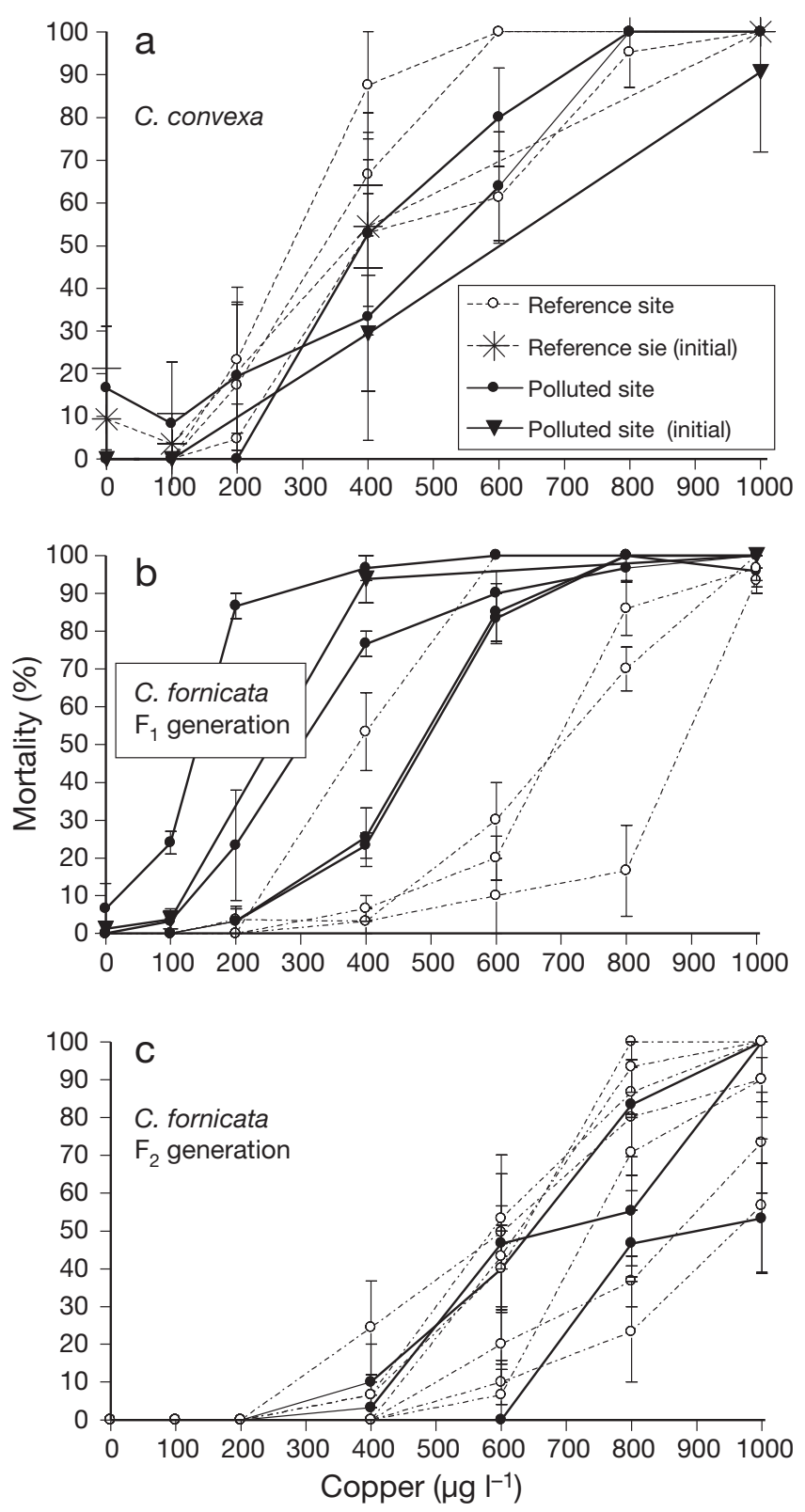

Fig. 2. Crepidula convexa and C. fornicata. Mortality for (a) juveniles of $C$. convexa and $(\mathrm{b}, \mathrm{c})$ larvae of $C$. fornicata exposed to copper for $96 \mathrm{~h}$. Parents of $C$. convexa and $\mathrm{F}_{1} C$. fornicata were collected from a reference site (Lynn Harbor, Nahant, Massachusetts) or a polluted site (New Bedford Harbor, Fairhaven, Massachusetts) and kept in artificial seawater until offspring were released. $\mathrm{F}_{2}$ larvae of $C$. fornicata are the offspring of laboratory-reared adults whose parents were collected from each site as indicated. Each line represents one $96 \mathrm{~h}$ acute copper toxicity test, while each point represents the mean $( \pm 1$ SEM) of 3 or 4 replicates with 4 to 8 juveniles or 10 to 20 larvae 
niles of C. Convexa from the polluted site population $\left(\right.$ mean $\mathrm{LC}_{50} \pm 1 \mathrm{SEM}=444.5 \pm 33.2 \mu \mathrm{g} \mathrm{Cu} \mathrm{l^{-1 }}$ ) were significantly more copper tolerant than juveniles from the reference site population (mean $\mathrm{LC}_{50} \pm 1 \mathrm{SEM}=$

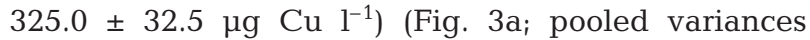
$t$-test, $t=2.52, \mathrm{df}=5, \mathrm{p}=0.05$ ).

Mortalities for $F_{1}$ and $F_{2}$ generation larvae of Crepidula fornicata during $96 \mathrm{~h}$ acute copper toxicity tests are shown in Fig. $2 \mathrm{~b} \& \mathrm{c}$, respectively (note that the results of 1 initial test were very similar to the results of later tests from the same site). The effect of site was not significant, while the effect of generation and the interaction of these 2 factors were both significant (Table 1). Post hoc tests, however, reveal that all differences were driven by the copper sensitivity of $F_{1}$ larvae from the polluted site population. $F_{1}$ larvae of $C$. fornicata from the polluted site population were significantly more sensitive to copper (mean $\mathrm{LC}_{50} \pm 1 \mathrm{SEM}=301.1 \pm 62.5 \mu \mathrm{g} \mathrm{Cu} \mathrm{l}^{-1}$ ) than $\mathrm{F}_{1}$ larvae from the reference site population (mean $\mathrm{LC}_{50} \pm 1$ $\mathrm{SEM}=636.3 \pm 205.8 \mu \mathrm{g} \mathrm{Cu} \mathrm{l} \mathrm{l}^{-1}$, Bonferroni, $\alpha=$ $0.0125, t=3.04, \mathrm{df}=15, \mathrm{p}=0.01$ ) and also significantly more sensitive than $\mathrm{F}_{2}$ larvae from the polluted site population (mean $\mathrm{LC}_{50} \pm 1 \mathrm{SEM}=712.9 \pm 92.0 \mu \mathrm{g}$ $\mathrm{Cu} \mathrm{l}^{-1}$, Bonferroni, $\alpha=0.0125, t=-3.43$, df $=15, \mathrm{p}<$ 0.005). Copper tolerance did not differ significantly betwefen different generations of larvae from the reference site population $\left(\mathrm{F}_{2}\right.$ reference site mean $\mathrm{LC}_{50} \pm$ $1 \mathrm{SEM}=697.1 \pm 59.5 \mu \mathrm{g} \mathrm{Cu} \mathrm{l^{-1 }}$, Bonferroni, $\alpha=$ 0.0125, $t=-0.59$, df $=15, \mathrm{p}=0.56$; Fig. 3b), nor between $\mathrm{F}_{2}$ larvae from the 2 sites (Bonferroni, $\alpha=$ $0.0125, t=-0.14$, df $=15, \mathrm{p}=0.89$; Fig. $3 \mathrm{~b}$ ).
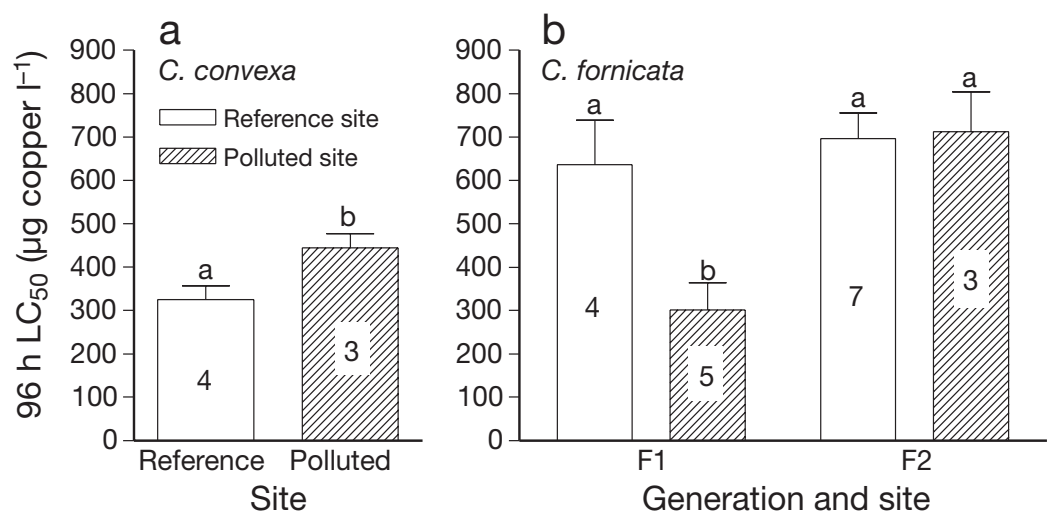

Fig. 3. Crepidula convexa and C. fornicata. Mean $\mathrm{LC}_{50}$ values for (a) juveniles of $C$. convexa and (b) larvae of $C$. fornicata from reference and polluted site populations. $\mathrm{LC}_{50}$ values determined by either conventional or trimmed Spearman-Karber method using the $\mathrm{LC}_{50}$ software program from the US Environmental Protection Agency. Numbers in the columns = number of toxicity tests to calculate the mean (+1 SEM) represented by each column; letters over the bars: significantly different $\mathrm{LC}_{50}$ values at $\alpha=0.05$ for C. Convexa or $\alpha=$ 0.0125 for $C$. fornicata (Bonferroni post hoc test with 4 comparisons, therefore $\alpha=0.05 \div 4)$
Table 1. Crepidula fornicata. Results of a 2-way Model I ANOVA of the $96 \mathrm{~h}$ copper $\mathrm{LC}_{50}$ values for 2 generations $\left(\mathrm{F}_{1}\right.$ and $\left.\mathrm{F}_{2}\right)$ from reference and polluted site populations (Lynn Harbor, Nahant, Massachusetts, and New Bedford Harbor, Fairhaven, Massachusetts, respectively)

\begin{tabular}{|lcccc|}
\hline Parameter & df & MS & $F$ & $p$ \\
\hline Site & 1 & 110159 & 4.08 & 0.06 \\
Generation & 1 & 241113 & 8.94 & 0.01 \\
Site $\times$ generation & 1 & 132953 & 4.93 & 0.04 \\
Residual & 15 & 26973 & & \\
\hline
\end{tabular}

\section{DISCUSSION}

We hypothesized that species with low dispersal would be better able to adapt to local conditions of persistently high metal concentration. Therefore, we expected that individuals of Crepidula convexa from the polluted site population would be more copper tolerant than individuals from the reference site population, but that individuals of the other species, C. fornicata, from the 2 sampled populations would have similar copper tolerance. The observed pattern for copper tolerance in juveniles of $C$. convexa met our expectations. While the observed pattern for $C$. fornicata was consistent with our hypothesis that this species would not evolve increased tolerance at the polluted site, the higher sensitivity of $F_{1}$ larvae from the polluted site compared to $F_{1}$ larvae from the reference site was unexpected. The observed pattern for $F_{2}$ larvae of C. fornicata, however, did meet our initial expectations; the copper tolerances of $\mathrm{F}_{2}$ larvae from the 2 sampled populations were essentially the same. Since the 2 generations of $C$. fornicata from the reference site population were also similar in copper tolerance, the low copper tolerance of larvae from the polluted site population in the $F_{1}$ generation probably reflected stress experienced by the parental generation at the polluted site, i.e. the greater sensitivity of $F_{1}$ larvae from the polluted site probably reflected negative maternal effects. If so, adult C. convexa at the polluted site would likely also have been stressed, since the 2 species are ecologically very similar (both are benthic suspension feeders). Therefore, the substantial difference between copper tolerances that we observed for $F_{1}$ generation juvenile C. convexa from the 2 sites may actually underestimate the difference we could expect for the $\mathrm{F}_{2}$ generation juveniles. 
Similarly, it could be that the greater copper tolerance of juvenile Crepidula convexa from the polluted site was caused by positive maternal effects (see Bernardo 1996 for a review of maternal effects in animals) rather than genetic adaptation. Such positive maternal effects may act through different mechanisms than the negative maternal effects discussed in the previous paragraph, offsetting or even counteracting them. The exposure of adults to contaminants at the polluted site might, for example, induce transcription of metallothionein mRNA during oogenesis, thereby increasing tolerance of offspring phenotypically rather than genotypically and counteracting negative maternal effects. For example, Lin et al. (2000) showed that increased cadmium tolerance for offspring of Cd-injected tilapia Oreochromis mossambicus was correlated with increased metallothionein mRNA in the adults' oocytes. In contrast, Tsui \& Wang (2005) found that, although maternal exposure to mercury increased offspring tolerance in the freshwater cladoceran Daphnia magna, it did not affect the concentration of metallothionein-like proteins in the offspring of exposed adults. Differences in metallothionein mRNA and protein in the eggs of adult C. convexa and C. fornicata before and after copper exposure would indicate whether there is the potential for a non-genetic cross-generational increase in copper tolerance for these species, and whether the potential for this type of trans-generational plasticity differs for the 2 species. In theory, plasticity is more likely in a species with wide dispersal, such as C. fornicata, since dispersive offspring are more likely to experience unpredictable environmental stress than the offspring of a species with limited dispersal (Sultan \& Spencer 2002). We would therefore predict greater plasticity of copper tolerance for $C$. fornicata than for $C$. convexa, which is the opposite of what we observed.

Selection for copper tolerance could only have occurred if genetic variation for this trait existed in the original population (Wright 1931), so it could be argued that the failure of Crepidula fornicata at the polluted site to adapt to local conditions may have been due to low genetic variation for the required trait. This seems unlikely, however, since Collin (2001) documented higher within-population genetic variation for mitochondrial DNA of C. fornicata compared to C. convexa. Laboratory selection for increased copper tolerance of $C$. fornicata coupled with genetic variation analysis (see Klerks \& Levinton 1989, Ward \& Robinson 2005) could test the hypothesis that this species does not have sufficient genetic variation in traits affecting copper tolerance to adapt to increased copper stress.

While the immediate benefits of increased tolerance to pollutants are clear for the individual organism, the longterm consequences for the population and community are often less obvious. Xie \& Klerks (2004b) reported many fitness costs, such as decreased fecundity, reduced size at birth, and shorter female life expectancy in a cadmium-resistant population of the least killifish Heterandria formosa. Such population-level declines in fitness can change community structure directly, since some species can adapt to increased pollution, while other species cannot (Blanck 2002). Pollutants can also change community structure indirectly by impacting parasite-host or predator-prey relationships (Lefcort et al. 2002) or by shifting the balance in competition for a limited resource (Johnston \& Keough 2003). Another community-level impact of increased tolerance involves the trophic transfer of toxic elements, which would be exacerbated when the mechanisms for increased tolerance result in elevated tissue concentrations of the toxic elements (Rainbow et al. 2004). Further studies on fitness costs and mechanisms of increased copper tolerance in Crepidula convexa, the extent to which C. convexa competes for food and substrate with other species, and the relative impact of parasites and predators on metaladapted populations are necessary to determine the wider ramifications of increased copper tolerance in populations of this species.

While our results support the hypothesized relationship between copper tolerance and species dispersal, our experiments were not designed to examine the underlying mechanism or mechanisms accounting for this difference. Rainbow et al. (1999) did not find a relationship between dispersal potential and metal uptake rates for an amphipod species that broods its young and 2 species of crab that release planktonic larvae, but it is possible that any or all of those species depend on mechanisms other than changes in metal uptake to tolerate high metal stress. Experiments testing for differences in cellular compartmentalization of copper, tissue-specific copper concentrations, and copper assimilation and elimination rates would help to reveal possible mechanisms for the increased tolerance we have documented for $C$. convexa living in highly polluted conditions (Lin et al. 2000, Rainbow et al. 2004, Xie \& Klerks 2004a).

Our studies do not indicate that the increased copper tolerance that we documented for Crepidula convexa is caused by copper alone as the selective agent. New Bedford Harbor is contaminated with a variety of persistent pollutants, including PCBs, PAHs, and metals (Pruell et al. 1990). Selection for tolerance of $C$. convexa to another pollutant may have resulted in physiological mechanisms that were pre-adaptive for copper tolerance, and these possibilities should also be explored.

Our study is the first to support a connection between dispersal potential and metal tolerance in marine invertebrates. While we found that 1 species (Crepidula convexa) from a polluted site produced off- 
spring with increased metal tolerance, we also found that a closely related species ( $C$. fornicata) from the same environment produced offspring with reduced metal tolerance. Both of these effects were long term, since the parents had been kept in artificial seawater in the laboratory for several months before they released the offspring used in our studies. Adaptation to local conditions may help species with limited dispersal to counteract negative maternal effects, while species with greater dispersal fare poorly in the same stressful environment. Further experiments with other closely related species that differ primarily in dispersal potential (see Bohonak 1999 for review) are necessary to validate this apparent relationship between local adaptation, negative maternal effects, and dispersal potential across a range of taxonomic groups.

Acknowledgements. The authors thank F. Chew, S. Lewis, and W. Robinson for all of their suggestions in the design and analysis of these experiments. We are especially grateful to W. Li for providing several mated pairs of C. fornicata for our experiments on maternal effects. This work was supported in part by funding from the Conchologists of America and the Tufts Grants in Aid of Research. We also thank W. Robinson and 5 anonymous reviewers for their helpful suggestions on drafts of this manuscript.

\section{LITERATURE CITED}

Bayne BL, Gabbott PA, Widdows J (1975) Some effects of stress in adults on eggs and larvae of Mytilus edulis L. J Mar Biol Assoc UK 55:675-689

Bernardo J (1996) Maternal effects in animal ecology. Am Zool 36:83-105

Blanck H (2002) A critical review of procedures and approaches used for assessing pollution-induced community tolerance (PICT) in biotic communities. Human Ecol Risk Assess 8:1003-1034

Bohonak AJ (1999) Dispersal, gene flow, and population structure. Q Rev Biol 74:21-45

Burton RS, Feldman MW (1981) Population genetics of Tigriopus californicus. 2. Differentiation among neighboring populations. Evolution 35:1192-1205

Collin R (2001) The effects of mode of development on phylogeography and population structure of North Atlantic Crepidula (Gastropoda: Calyptraeidae). Mol Ecol 10: 2249-2262

Conklin EG (1897) The embryology of Crepidula, a contribution to the cell lineage and early development of some marine gastropods. J Morphol 13:1-227

Fretter V, Graham A (eds) (1994) British prosobranch molluscs: their functional anatomy and ecology. The Ray Society, Andover

Johnston EL, Keough MJ (2003) Competition modifies the response of organisms to toxic disturbance. Mar Ecol Prog Ser 251:15-26

Kawecki TJ, Ebert D (2004) Conceptual issues in local adaptation. Ecol Lett 7:1225-1241

Editorial responsibility: Pei-Yuan Qian (Contributing Editor), Kowloon, Hong Kong, SAR
Klerks PL, Levinton JS (1989) Rapid evolution of metal resistance in a benthic oligochaete inhabiting a metal-polluted site. Biol Bull (Woods Hole) 176:135-141

Lefcort $\mathrm{H}$, Aguon MQ, Bond KA, Chapman KR and 5 others (2002) Indirect effects of heavy metals on parasites may cause shifts in snail species compositions. Arch Environ Contam Toxicol 43:34-41

Lin HC, Hsu SC, Hwang PP (2000) Maternal transfer of cadmium tolerance in larval Oreochromis mossambicus. J Fish Biol 57:239-249

Lord A (1986) Are the contents of egg capsules of the marine gastropod Nucella lapillus (L.) axenic? Am Malacol Bull 4: 201-203

Morgan AJ, Kille P, Sturzenbaum SR (2007) Microevolution and ecotoxicology of metals in invertebrates. Environ Sci Technol 41:1085-1096

Pechenik JA (1984) The relationship between temperature, growth rate, and duration of planktonic life for larvae of the gastropod Crepidula fornicata (L.). J Exp Mar Biol Ecol 74: 241-257

Pruell RJ, Norwood CB, Bowen RD, Boothman WS, Rogerson PF, Hackett M, Butterworth BC (1990) Geochemical study of sediment contamination in New Bedford Harbor, Massachusetts. Mar Environ Res 29:77-101

Rainbow PS, Amiard-Triquet C, Amiard JC, Smith BD, Best SL, Nassiri Y, Langston WJ (1999) Trace metal uptake rates in crustaceans (amphipods and crabs) from coastal sites in NW Europe differentially enriched with trace metals. Mar Ecol Prog Ser 183:189-203

Rainbow PS, Geffard A, Jeantet AY, Smith BD, Amiard JC, Amiard-Triquet C (2004) Enhanced food-chain transfer of copper from a diet of copper-tolerant estuarine worms. Mar Ecol Prog Ser 271:183-191

Rand GM (ed) (1995) Fundamentals of aquatic toxicology. Taylor \& Francis, Philadelphia, PA

Robinson WE, Coffey TJ, Sullivan PA (1990) New England Aquarium's ten year Boston Harbor monitoring program. First report (March 1987-July 1989). Report No. 1, New England Aquarium, Boston, MA

Sultan SE, Spencer HG (2002) Metapopulation structure favors plasticity over local adaptation. Am Nat 160:271-283

Tsui MTK, Wang WX (2005) Multigenerational acclimation of Daphnia magna to mercury: relationships between biokinetics and toxicity. Environ Toxicol Chem 24:2927-2933

US Environmental Protection Agency (2002) Methods for measuring the acute toxicity of effluents and receiving waters to freshwater and marine organisms. Methods Manual EPA-821-R-02-012, USEPA, Washington, DC

Ward TJ, Robinson WE (2005) Evolution of cadmium resistance in Daphnia magna. Environ Toxicol Chem 24:2341-2349

Wright S (1931) Evolution in Mendelian populations. Genetics 16:97-159

Xie LT, Klerks PL (2004a) Changes in cadmium accumulation as a mechanism for cadmium resistance in the least killifish Heterandria formosa. Aquat Toxicol 66:73-81

Xie LT, Klerks PL (2004b) Fitness cost of resistance to cadmium in the least killifish (Heterandria formosa). Environ Toxicol Chem 23:1499-1503

Xie ZC, Wong NC, Qian PY, Qiu JW (2005) Responses of polychaete Hydroides elegans life stages to copper stress. Mar Ecol Prog Ser 285:89-96

Zar JH (1999) Biostatistical analysis. Prentice Hall, Upper Saddle River, NJ 